\title{
OBSERVATIONS ON THE LIFE HISTORY OF PTERODONTIA FLAVIPES GRAY. (DIPTERA.)*
}

By J. L. KInG, Wooster, Ohio.

\section{INTRODUCTION.}

During the summer of 1915, while at Gypsum in northern Ohio, the writer found several peculiar dipterous larvæ under burlap bands which had been placed around the trunks of some apple trees. The adults reared from these proved to belong to the genus Pterodontia of the family Cyrtidæ. From the literature at hand it was evident that little had been published concerning the habits of this interesting family. This stimulated further observation, the results of which are recorded in this paper. Later a more thorough study of the literature was made, particularly of those articles which deal with the life histories of the members of the family. These have been briefly summarized and are appended after each special topic.

The writer wishes to express his gratitude to Professor A. D. MacGillivray for his kind interest and help in the preparation of this paper. Thanks are also due to Mr. J. R. Malloch, of the Illinois State Laboratory of Natural History for the identification of the species, and to Mr. Nathan Banks for the determination of the host spiders.

\section{THE MATURE LARVA OF PTERODONTIA.}

On July 20, 1915, three larvæ were found under the burlap bands which surrounded the trunks of some large apple trees. In all cases the larvæ were found either suspended in abandoned spider webs or entangled by threads and resting partly on the bark or on the burlap. When suspended, their position was maintained by the web adhering to their sticky body surface. In two cases the remains of spiders were found near the larvæ. The largest larva, measuring $8 \mathrm{~mm}$. in length, had emerged from the abdomen of an Epeirid spider, Epeira sericata Clerk, leaving the abdomen through a comparatively small hole on the ventral side, in the region of the anterior lung-slit. From

\footnotetext{
*Contribution from the Entomological Laboratories of the University of Illinois, No. 49, and the Ohio Experiment Station, Wooster, Ohio.
} 
the size of the larva and the scant remains of the abdomen, it would seem that the larva had almost filled the entire abdomen. The cephalothorax and legs were also eaten out so that the remains resembled a cast skin, except for the fact that the cephalothorax was not broken. The smallest larva, which was $6 \mathrm{~mm}$. in length, had emerged under similar conditions but from a smaller spider. In the third case no remains of a spider were noted.

Since the foregoing notes were written, five larvæ of this species have been found to be parasites of Lycosid spiders. Concerning the identity of these, Mr. Nathan Banks states that he is almost certain the species is Lycosa pratensis Emer., the doubt of the question being due to the partial destruction of the specimens by the parasites.

The larvæ vary in length from 6 to $8 \mathrm{~mm}$. and are oval in form with a strong constriction marking off the smaller cephalic end (Fig. 8). They are of a creamy white color and on the dorso-meson show four dark areas which pulsate in a slow, rhythmic manner. The body-wall is soft and delicate, the external surface being smooth and sticky, causing the web and small particles of dirt to adhere to it. The segmentation of the body is not very distinct; however, the cast skins show twelve body segments. The four anterior segments are not as well defined as the others and seem to be softer and more delicate. The second segment bears a pair of closed spiracles which connect with large tracheal tubes. On the ventral surface of the fifth to the eleventh segments are seven pairs of padlike areas which are armed with minute crotchets. The caudal spiracles are located on the dorsal surface of the twelfth, or caudal, segment. They are larger than the anterior spiracles and have a distinct opening. In the living larva they, are capable of being slightly extended or retracted.

The mouth-parts have been studied from cast larval skins. The external mouth-parts consist of two minute bidentate mandibles, and two mouth-hooks (Fig. 8a, m. and m. h.). These structures are attached on each side of the small mouth opening. The internal structure consists of a pharyngeal plate in the form of a shallow trough with two curved anterior arms which meet and form a circular loop above the mouth cavity (Fig. 8a, ph. p.). Attached to the margins of the pharyngeal plate and loop is a tough membrane which forms the dorsal 
roof of the pharynx. Whether muscular attachment converts this structure into a pharyngeal pump or whether further parts are wanting cannot be determined until additional material is at hand.

\section{LITERATURE ON THE LATE LARVAL STAGES OF THE CYRTIDA.}

In Europe Menge (15)* in 1863 was the first to record that the Cyrtidæ are parasitic in the bodies of spiders. He obtained from the nest of a spider, Clubiona putris, a larva which proved to be that of Oncodes pallipes Erich. (Henops marginatus). Further examination of the nest of the spider revealed the shriveled remains of the spider with a large hole in the underside of the abdomen. Brauer (2) in 1869 described and figured the larva and pupa of Astomella lindenii, which were found in the burrow of a spider, Ctenzia ariana. According to Brauer's (3) observations, the larvæ, while lodged within the abdomen of the host, breathe by placing their caudal spiracles in one of the lung-chambers of the spider. The fully grown larva of Astomella lindenii is $10 \mathrm{~mm}$. in length and is comparatively thick. The body has twelve segments. The head segment is small and is fitted with mandibles and maxillæ. The larva is amphipneustic, having prothoracic and caudal spiracles.

In the United States several observers have recorded the finding of Cyrtid larvæ, though they have given us no detailed descriptions of them. Among the most important of these are Emerton's (4) observations on the larvæ of Acrocea lasciata Wied. The larvæ were found clinging to the deserted webs of Amaurobius sylvestris. They were suspended in the webs, heads uppermost, clinging to it with their jaws and also supported by threads under and around them. The shriveled remains of the spiders were found in the webs. The larvæ are described as soft, white maggots from one-eighth to one-fourth of an inch in length with the hinder half of the body thicker than the front half and nearly spherical. A single figure of the larva is shown. Johnson (7) in 1903 is reported as having reared the same species from Lycosa stoni. He states that many spiders, perhaps twenty-five per cent, are parasitized by these flies. Montgomery (16) in 1903 records the occurrence of Cyrtid

*Numbers refer to the bibliography, page 000. 
larvæ as parasitic in spiders of the genus Lycosa which he had under observation. One male and six female spiders were found to be parasitized and in one case two larvæ issued from a single spider. This observer notes that a short time before the parasite escapes from the body of its host, the spider acts in a peculiar manner, walking about spasmodically and often spinning aimlessly. After the soft parts of the body of the spider are eaten away the parasite emerges through a hole which it makes in the abdomen; this emergence kills the host. The bulk of the body of each parasite is noted as being almost equal to that of the abdomen of the host.

\section{THE PUPA OF PTERODONTIA.}

The pupation of the larvæ took place July 21, or the day after the larvæ left their hosts. The pupa (Fig. 9) was $6 \mathrm{~mm}$. in length and when first formed was light creamy-white, but soon after it turned to a pale yellowish-brown color. The surface is smooth, shining, and without setæ or spines except for a prominent V-shaped crest on the head. This is composed of a large number of irregularly barbed, clublike processes (Fig. 9a). The various adult parts, as the rounded head which is quite prominent, the wings, tegulæ and legs are quite distinctly outlined in the pupa. On the cephalo-lateral aspect of the thorax there is a single pair of spiracular projections and caudad of these the thorax is elevated into a rounded hump. The abdomen consists of eight segments, the anterior three each bearing a pair of elevated spiracles. The caudal segments are telescoped into the preceding segments, giving the abdomen a truncated appearance. The lateral line caudad of the third spiracle is marked by a dark furrow. The duration of the pupal period was seven days.

\section{LITERATURE ON THE PUPÆ OF THE CYRTIDÆ.}

The pupa of Astomella lindenii has been described by Brauer (2). It differs from the pupa of Pterodontia in several characteristics; namely, the head is less prominent and lacks the crest of spines; the thorax bears on the dorso-meson a row of spines. The abdomen shows seven segments, the first six of which bear spiracles. The empty pupal case is dark brown spotted with light yellow. 
Of the American species the pupa of Oncodes costatus Loew is described by Malloch (12). The description was made from a single pupal exuvium. In most respects the pupa seemed to be similar to that of Pterodontia but differs in having five spiracles; the anterior four are on prominent protuberances. The crest of barbed spines is also wanting in this species.

\section{THE ADULT.}

Female.-(Fig. 1) Head spherical and small in proportion to the thorax. Eyes contiguous, large, black, and densely clothed with long, black setæ. Ocelli three in number. Antennæ inserted ventrad of the compound eyes; they consist of three segments, the third of which bears three or four terminal setæ. The mouth-parts are obsolete. Thorax large, mesonotum piceous and shining; scutellum light yellow or sometimes light brown. Ventral parts of thorax dark brown. The entire thorax is clothed with long, black hairlike setæ. Legs pale yellow except the femora which are somewhat darker yellow or brownish. Tegulæ large and brownish in color. Wings slightly clouded, membrane undate, veins dark yellow or brown. Venation as shown in Figure 3. The toothlike projection near the distal end of the costal margin is wanting in the female. Abdomen large, globular and inflated. First abdominal segment black or brownish. Second abdominal segment yellow or testaceous and with the cephalic margin black; in some individuals this segment has a median triangular black spot. The third segment in most specimens is entirely yellow or testaceous; however, a few specimens have a median, black, triangular spot on the cephalic margin. The remaining segments are yellow or testaceous. Ventral surface of abdomen dark brown. The entire surface of the abdomen is clothed with long, black, hairlike setæ. The length varies from 4 to 8 $\mathrm{mm}$. with an average of $6.5 \mathrm{~mm}$. taken from a series of twenty-six females.

Male.-The male differs from the female in the following points: Thorax broad and more robust than that of the female. Four posterior femora black. Wing veins yellow, toothlike projection on the costal margin prominent (Fig. 3). Second abdominal segment shining black. Third segment testaceous and with a large median rectangular spot. Fourth segment testaceous but sometimes with a median oval black spot. The remaining segments are testaceous (Fig. 2). Length 6 to 9 $\mathrm{mm}$., average about $7 \mathrm{~mm}$.

A closely allied western species of this genus has been described by Osten Sacken (17). This species, Pterodontia misella, so closely approaches Pterodontia flavipes Gray (6) that it is sometimes difficult to determine to which species a variety may belong. Williston (19) says concerning P. misella O. S.: "I have several specimens of this species from Washington 
varying from six to nine millimeters in length. The black markings of the abdomen vary in extent, and from comparison with eastern specimens ( $P$. flavipes Gray), I can find no constant difference and believe them to be the same." From comparisons made by the writer it is noted that the species, $P$. misella, seems to be founded on color pattern alone, for there seems to be no morphological dissimilarity. The only solution to such questions of the identity of a species seems to be by a careful study of a series of specimens which have been reared from known forms.

\section{OVIPOSITION OF PTERODONTIA.}

On August 7, while passing by the border of an open hickory grove, the writer observed several large flies hovering up and down the trunks of some large hickory trees. The capture of one of these proved the species to be identical with those reared from the larvæ found on the apple trees. The flies were observed for some time; during this period they hovered up and down the tree trunks from about a foot above the ground to a height of ten to fifteen feet. They flew always on the leeward side and from one to two inches away from the surface of the bark. Occasionally they would come to rest upon the bark, and at such times they were so sluggish that it was possible to pick them up in one's fingers. Though the flies were observed very closely. they were not seen to deposit eggs or to pay any attention to the gray jumping spiders that crept over the bark.

Upon returning to the laboratory and transferring a living specimen to a bell-jar, the writer noted that the handkerchief in which it had been carried was sprinkled with minute black specks, which on examination proved to be eggs. Further observation revealed the fact that the eggs were forcibly discharged from the ovipositor in extremely rapid succession and that the eggs when first deposited were coated with a sticky substance which caused them to adhere to whatever they hit or fell upon.

The following day some of the trees in the grove were banded with narrow strips of clean, white paper. After a brief period two flies appeared hovering over the surface of the bark in the same manner as observed during the previous day. This time, however, with the aid of the white paper strips, their actions were easily interpreted. By watching closely as the flies hovered 
over the paper strips, one could see the eggs appear upon the paper as minute black specks sprinkled in irregular rows. An examination of the bark of the trees showed the leeward side of each tree to be literally sprinkled with thousands of eggs. One of the ovipositing flies was so bold as to hurl her eggs on to the face and hands of the writer while making these observations.

The eggs contained in the handkerchief were removed to a watch glass by means of a soft brush. Many of the eggs were lost or crushed during the process; however those remaining numbered 2,300. All of these were deposited by a single female in a period of not more than forty-five minutes.

A second series of egg counts has been made from three females taken July 14, 1916 . The counts represent the entire number of eggs deposited by each female from the time of capture until death. They are as follows: No. one, 987; No. two, 3,344; and No. three, 3,977. Most of these eggs were deposited during the morning of the first day, and in no case did the captive flies live for more than two days.

\section{THE EGGS OF PTERODONTIA.}

The eggs (Figs. 4 and 5 ) are very minute, measuring $.18 \mathrm{~mm}$. in length and $.15 \mathrm{~mm}$. in width. They are slightly compressed and pear-shaped in outline and are of a dull black color. Under high magnification the chorion has a granular appearance as shown in Figure 6 . When first deposited, the eggs are coated with an adhesive substance.

\section{LITERATURE ON THE OVIPOSITION AND EGGS OF THE CYRTIDE.}

Brief notes are to be found concerning the eggs of several European species. Friedrick Stein (18) in 1849 records finding the eggs of Oncodes fuliginosus Erich. in mid-June on the stems of Equisetum limosum which was growing in a low, wet meadow not far from Berlin. The eggs had been despoited in rows in large numbers and covered the plants thickly. The eggs are described as small, black, pear-shaped bodies. In 1894 König (10) described the eggs and young larvæ of what he thought were those of either Oncodes gibbosus or $O$. zonatus, since he took both species in the same locality. The eggs had been deposited on dead branches which had been used to make a fence. The smallest twigs were thickly covered with rows of 
dark brown or blackish, pear-shaped eggs deposited so as to stand on the small end. The larvæ emerged from the free end of the egg through a lidlike opening in the shell.

An interesting note on the oviposition of a New Zealand species, Oncodes brunneus Hut. (Henops brunneus), is given by W. M. Maskell (13) as follows: "About October last a resident in the Wairarapa District sent down to the Colonial Museum a few twigs of apple, quite covered with some black substance, amongst which were slowly crawling about half a dozen rather large flies; and he desired some information on this, which he considered a new 'blight,' stating that it occurred on both apple and peach trees in his garden. The specimens were referred to me, and at first sight I thought the sooty, black coating to be the usual fungus accompanying scale insects, the flies being unconnected with it. Closer examination, however, showed that the black mass was really composed of many thousands of eggs; and the flies were soon observed to be still laying more of these eggs on the twigs, until in a short while it was so thickly covered with them as to be quite hidden."

\section{THE NEWLY HATCHED LARVA OF PTERODONTIA.}

From eggs which were deposited on August 7th, larvæ emerged September 7 th and 8th, thus making an incubation period of 32 to 33 days. The larvæ made their exit through a lidlike opening at the small, or pointed, end of the eggs. The newly hatched larvæ (Figs. 11 and 12) are Campodea-like in form, resembling quite strikingly the planidium larvæ of Perilampus* or the triungulin larvæ of Stylops. They are dark brown or black in color and measure $0.25 \mathrm{~mm}$. in length, exclusive of the caudal setæ. The body consists of twelve segments including the head.

The head segment is distinct though it is firmly joined to the prothoracic segment. The head appendages consist of two ventral mouth-hooks and two caudo-lateral antennalike setæ. The details of the mouth-parts have not been worked out. There is, however, a large internal pharyngeal skeleton which is very distinct. The latter structure consists of two strongly chitinized dorsal plates (Figs. 7 and 11) and a slightly chitinized

*See Smith, H. S. The Chalcidoid genus Perilampus and its relations to the problem of parasite introduction. U. S. Dept. Agr. Bur. Ent., Tech. Series No. 19, 1912, pp. 33-69. 
ventral plate, which is visible only in a lateral view (Fig. 7). The pharyngeal plates seem to fuse and form a median tooth or beaklike rostrum which is capable of being slightly protruded.

The thoracic and abdominal segments are strongly chitinized and consist of distinct tergal and sternal plates. In newly hatched larvæ the body-plates and segments are quite closely drawn together, but in specimens which were removed from their hosts the segments were distended, the terga and sterna being separated by a pleural membrane (Fig. 7). The dorsal and ventral surfaces of the thorax and abdomen are elaborately armed with long and short spines and broad chitinous scales. The dorsal scales are broad and palmate, with nine to eleven points (Figs. 13 and 14). On the dorsum they are limited to the mesothoracic and metathoracic terga, the remaining segments being armed with both long and short spines. There are also a number of minute, round, clear spots, which occur only on the terga. On the venter, the scales occur on all of the sterna except the prothoracic and caudal segments. On the sterna of the second and third thoracic segments and the first abdominal segment the scales are broad and have seven points or digits; the remaining segments are armed with smaller scales which for the most part are three, five, and seven pointed. The scales are firmly set into the body-wall through a funnellike opening (Fig. 16). The caudal end of the eighth abdominal segment is membranous and prolonged, forming a disk or sucker which serves for attachment. On each side of the caudal disk is a long, stiff, spring-bristle which is used in leaping. Spiracles seem to be wanting. On the caudal margin of the eighth abdominal terga are two crescentic areas which resemble spiracles. These, however, are notches in which the caudal setæ, or spring-bristles, rest when the larva stands erect on its attachment disk.

\section{HABITS OF THE LARVA.}

The young larvæ are very active, particularly at night when they are in almost constant action. Locomotion is accomplished in several ways. There is a looping movement accomplished by attaching first the head and then the attachment disk in a manner similar to that of a leech. A second method, that of leaping, is effected by the larva standing erect on the attachment disk with the spring-bristles bent at right angles to the 
body and toward the dorsal surface; when ready to leap a sudden straightening of the setæ in a posterior direction lifts the larva into the air. In this way the larva can leap five or six millimeters. This method of jumping is quite different from that of the cheese-maggot, Piophila casei, and some of the Itonididæ which leap by first bringing the head and tail ends together and then suddenly straightening the body. A third method of locomotion occurs when the larvæ are on a moist surface, when they crawl by extending and contracting the body segments.

On September 10th, the larvæ were separated into two lots and were liberated in large petri dishes which contained bark. A few spiders of the genus Epeira and spider's eggs were also placed in the dishes with the larvæ. In both dishes most of the larvæ died after three days and in five days no living larvæ were found, though the spiders seemed to be normal and fed upon flies for several days.

On September 27th, or 17 days after confinement, one of the smallest spiders was found in a dying condition. The abdomen of this specimen was removed and carefully dissected. Three spiny larvæ were found in the body near the dorsal surface. The larvæ were alive and active and showed no change other than a distension of the body segments.

Some time later the cephalothorax and legs of this same spider were cleared in carbol-xyol and mounted in balsam. This method rendered the thorax almost transparent and enabled one to locate the parasites in their exact position. In all, twenty-seven larvæ were found in the cephalothorax and legs. These were found in the following parts: One in the first segment of the right palp, one in each trochanter of the anterior pair of legs, two in the trochanter of the second right leg, one in the femur of the third right leg, one in the femur of the fourth left leg, one in the patella of the fourth left leg, and the remaining nineteen were in the cephalothorax above the ental openings of the coxæ or near them (Fig. 10).

On November 29, 1915, a second spider died. The death of this specimen was doubtless due to injury received while moving the specimen from Ohio to Illinois, for the thorax was dented and one leg partly crushed; however, it lived for seventy-nine days after it had been put with the young Cyrtid larvæ. This 
specimen was too large to clear; hence the entire spider was immediately dissected. One spiny larva was found in the abdomen and three in the thorax. As in the first case, the larvæ were alive and active but no change had taken place. All of these larvæ were carefully examined, and in all cases the spines and scales of the body and the caudal setæ were found to be intact.

Although the foregoing cases of parasitism were brought about under abnormal conditions in the presence of hundreds of larvæ, they manifest several interesting points: First, it would seem from the large number of larvæ found in the cephalothorax thorax and legs of the host that most of the larvæ enter the body of the spider by penetrating the thin membrane at the articulations of the legs. The broad scalelike plates and spines undoubtedly enable the larvæ to penetrate the host and aid in traveling through the muscles of the thorax. Second, the occurrence of first-stage larvæ in the host seventy-nine days after entering, and during November, would lead to the conclusion that the growth of the parasite does not start until after the hibernating season of the host is over. Third, the location of the larvæ in the cephalothorax thorax further indicates that the first-stage larvæ do not have any connection with the respiratory organs of the host. This is further confirmed by the lack of spiracles.

\section{LITERATURE ON THE EARLY LARVAL STAGES OF THE CYRTIDÆ.}

Very little has been published concerning the early larval stages of the species of this family and as far as could be ascertained none of the American species have been described. Of the European species only the larvæ of Oncodes have been described. Professor Brauer (2) in quoting from his correspondent, Dr. Gerstacker, states that this observer reared larvæ from the eggs of Oncodes zonatus. He does not describe the larvæ further than to say that they were very active and sprang like the cheese-maggot, Piophila casei. In 1894, König (10) found eggs and young larvæ of Oncodes. The exact identity of the larvæ is not certain, though he took the species to be either $O$. gibbosus or $O$. zonatus, since adults of both species were taken in the same locality. The larvæ are figured and described in detail. They are described as being $0.3-0.4 \mathrm{~mm}$. long and of a dark brown or black color. The body is made up 
of eleven distinct segments, and is armed with setæ. The head is small and not well defined. The mouth-parts consist of two external mouth-hooks, a median tooth and two fleshy lobes, the latter functioning as attaching organs. There are two internal pharyngeal plates. On the caudal segment is a second attaching organ and four short spring-bristles; thus the larvæ move about by a looping movement or by jumping. König states that some of the larvæ were found attached to Podurans.

The larva of a New Zealand species of Oncodes has been figured and described by Maskell (13) in 1888. The larvæ are similar to those described by König. They differ from them, however, in the following points: The body is made up of twelve segments and the head is distinct. There are two mouthhooks and a fleshy lobe which functions as an attachment organ. The caudal segment terminates in a point with three spines. There are two stout spring bristles and the penultimate segment has two spiracles. The larvæ are said to walk in a looping fashion.

\section{CONCLUSIONS.}

From the account herein presented, we may conclude that the method of oviposition of Pterodontia flavipes is unique; however, the potential reproductive power of the females seems to be common with other members of the family, as is illustrated by the observations of Stein (18), König (10) and Maskell (13). It is undoubtedly one of the adaptations exacted by a parasitic mode of life in which there is a large percentage of mortality in the first larval stages.

In general the activities of the newly hatched larvæ of Pterodontia are like those of Oncodes. However, morphologically, they are more highly specialized for their parasitic mode of life, as is manifest by the lack of spiracles and by the presence of elaborate scalelike plates on the body.

\section{BIBLIOGRAPHY.}

1. Aldrich, J. M. 1905. Catalogue of North American Diptera, Smithsonian Inst., Washington.

2. Brauer, Fredrich. 1869. Beitrag zur Biologie der Acroceriden, Verh. k. k. zool-botan. Gesel. Wien 19: 737-740; P1. 13, Figs. 1-6.

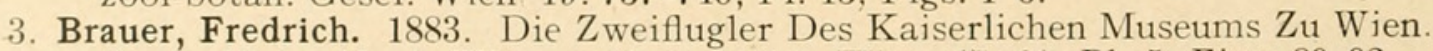
Denk. Kais. Akad. Wiss. mathem-natur. Wien, 47: 61; P1. 5, Figs. 89-92.

4. Emerton, J. H. 1890. An internal dipterous parasite of spiders, Psyche, 5: 404; two figs. 

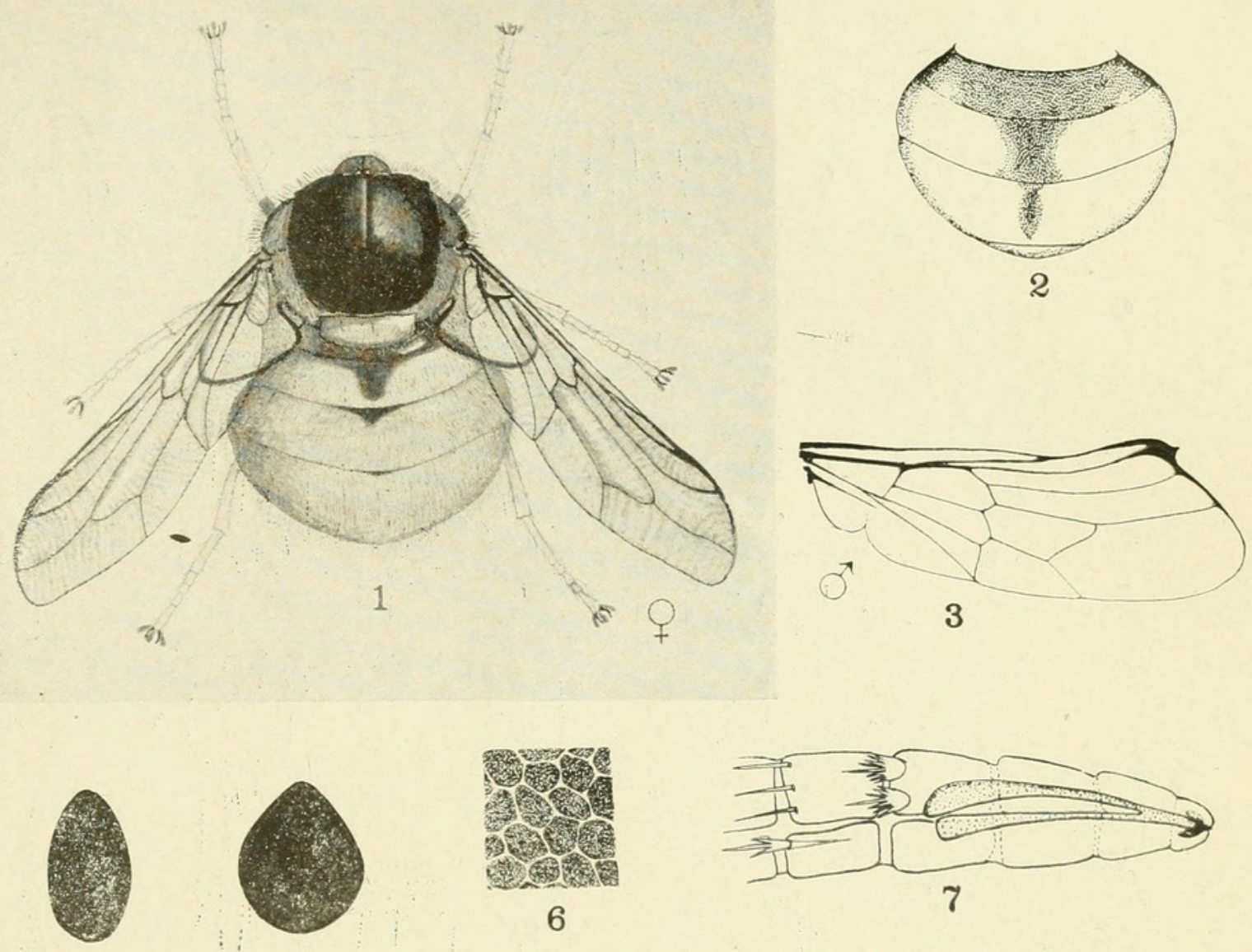

6

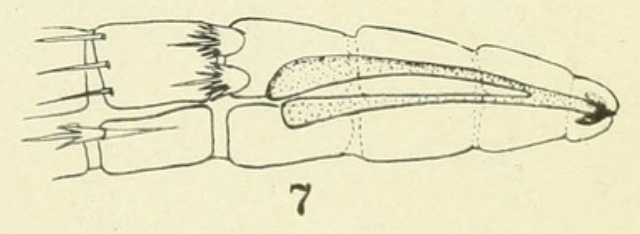

5
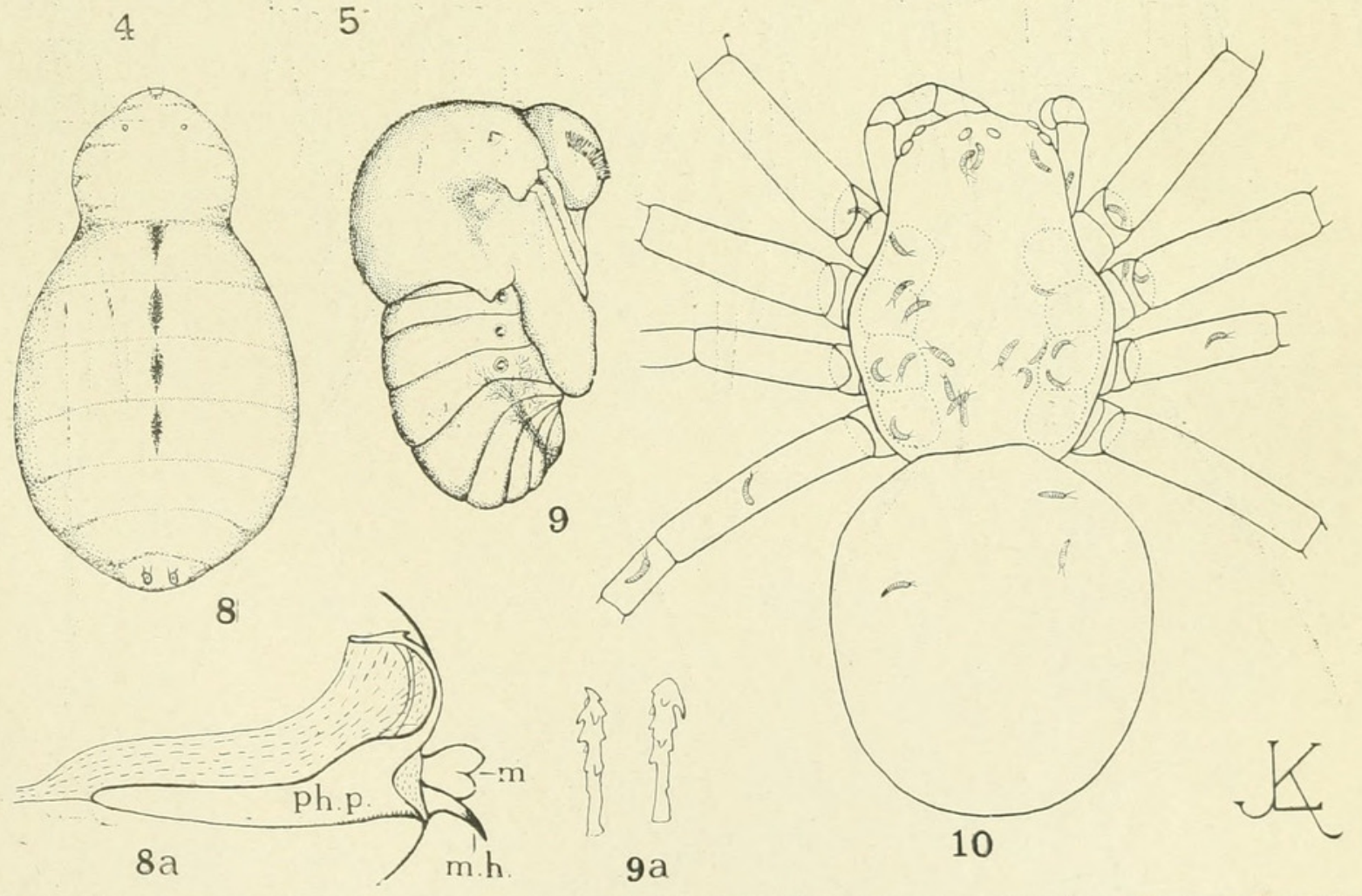

J I. King 


\section{$2 \mathrm{BHL}$ Biodiversity Heritage Library}

King, J L. 1916. "Observations on the life history of Pterodontia flavipes Gray (Diptera)." Annals of the Entomological Society of America 9, 309-321. https://doi.org/10.1093/aesa/9.3.309.

View This Item Online: https://www.biodiversitylibrary.org/item/43630

DOI: https://doi.org/10.1093/aesa/9.3.309

Permalink: https://www.biodiversitylibrary.org/partpdf/18740

\section{Holding Institution}

Smithsonian Libraries

\section{Sponsored by}

Smithsonian

\section{Copyright \& Reuse}

Copyright Status: NOT_IN_COPYRIGHT

This document was created from content at the Biodiversity Heritage Library, the world's largest open access digital library for biodiversity literature and archives. Visit BHL at https://www.biodiversitylibrary.org. 